\title{
Social skills, empathy, love, and satisfaction in the family life cycle
}

\author{
Habilidades sociais, empatia, amor e satisfação \\ no ciclo vital familiar
}

Roberta de Souza Nogueira BARROS ${ }^{1}$ (D) 0000-0003-3240-1960
Adriana Benevides SOARES ${ }^{\text {(ID) 0000-0001-8057-6824 }}$
José Augusto Evangelho HERNANDEZ² ${ }^{\text {(D) 0000-0001-9402-7535 }}$

\begin{abstract}
This study verified the predictive relationships between social skills, beliefs about love and marital satisfaction in the family life cycle. The participants of this study were 446 married adults, of both sexes, living in the metropolitan area of the city of Rio de Janeiro, Brazil. The explanatory variables that contributed most to the marital satisfaction of men were passion, proactive self-control, decision/commitment, and for women they were commitment, affective sensitivity, decision/ commitment, and passion. It was concluded that the dimensions related to love constructs were more explanatory of marital satisfaction, except at the stage of couples with small children whose social skills were more prominent. These results may contribute to preparatory programs and therapies related to marital life.
\end{abstract}

Keywords: Family life cycle; Marital satisfaction; Romantic love; Social skills.

\section{Resumo}

Este estudo verificou as relações preditivas entre habilidades sociais, empatia, amor e satisfação conjugal no ciclo vital familiar. Os participantes deste estudo foram 446 adultos casados, de ambos os sexos, residentes na região metropolitana do Rio de Janeiro/RJ. As variáveis explicativas que mais contribuíram para a Satisfação Conjugal de homens foram a Paixão, o Autocontrole Proativo e a Decisão/Compromisso; e, para as mulheres, o Compromisso, a Sensibilidade Afetiva, a Decisão/ Compromisso e a Paixão. Concluiu-se que as dimensões do construto do amor foram mais explicativas da Satisfação Conjugal no ciclo familiar geral, exceto na etapa de casais com filhos pequenos, em que habilidades sociais foram mais proeminentes. Esses resultados podem contribuir para programas preparatórios e terapias relativas à vida conjugal.

Palavras-chave: Ciclo vital familiar; Satisfação conjugal; Habilidades sociais; Amor romântico.

1 Universidade Salgado de Oliveira, Programa de Pós-Graduação em Psicologia. R. Marechal Deodoro, 217, Bloco A, Centro, 24030-060, Niterói, RJ, Brasil. Correspondência para/Correspondence to: A.B. SOARES. E-mail: <adribenevides@gmail.com>.

2 Universidade do Estado do Rio de Janeiro, Instituto de Psicologia, Programa de Pós-Graduação em Psicologia Social. Rio de Janeiro, RJ, Brasil.

$\mathbf{v} \mathbf{v} \mathbf{v}$

Como citar este artigo/How to cite this article

Barros, R. S. N., Soares, A. B., \& Hernandez, J. A. E. (2019). Social skills, empathy, love, and satisfaction in the family life cycle. Estudos de Psicologia (Campinas), 36, el80032. http://dx.doi.org/10.1590/1982-0275201936el80032 
McGoldrick, Preto, and Carter (2015) created a scheme that considered the nature of the various stages, emotional processes, and tasks necessary for the evolution of the family's life course. The sequence of stages defined by the authors was as follows: young single individual, family without children, family with young children, family with adolescents, mid-life family and late stage family. Transitioning from one stage to another can impact family members and cause stress. In the present study, the relationships between social skills, empathy, romantic love, and marital satisfaction in an ad hoc adapted family life cycle of McGoldrick et al. (2015).

The formation of the couple begins from the union of two families, usually through marriage. The main tasks to be developed by the spouses in this first phase are the adjustment of their individualities, the rule-making of this new system, and the realignment between these and their own families and friends. The difficulties in developing these tasks can become problems for the couple (Abreu-Afonso, Leal, \& Proença, 2015).

With the birth of the first child, the couple must prioritize their union for performing household chores, parenting, dealing with financial issues, and the relationship with their families of origin. The birth of a child brings complex changes, transforming the couple into a family. Romantic relationships can be relegated to the background and conflicts over child care and education can emerge (Doss \& Rhoades, 2017).

At the stage when the couple has adolescent children, the issue is summarized in the coping between adolescents who seek greater independence to grow and parents who seek to restrict this impulse in safeguarding their physical integrity and responsibility. Parents need to adopt a balanced stance in the relationship based on dialogue, affection and respect, with limits when subsidizing their children's demands (Barreto \& Rabelo, 2015).

The phase of couples with children over 18 years of age is characterized by young individuals who gradually seek to make decisions and gain their autonomy from new and intense experiences, an exploration for their adult identity. Parents will have the arduous and complicated task of negotiating this process with their children. This may also mean a new test for spouses, as children may gradually cease to be the focus of attention, which can be reinvested in the couple. There may be more room for returning their own intimacy and sexual interest. Companionship and tranquility can emerge as important values for satisfaction. At the same time, the couple may experience the 40-50-year-old crisis and the need to reevaluate life and its meaning. In addition, the couple has to deal with the consequences of their parents' aging (Azambuja \& Jaeger, 2015; Dutra-Thomé \& Koller, 2014; Ponciano, 2015; Ponciano \& Féres-Carneiro, 2014).

In this evolutionary process, it is possible that the individual's social skills may influence the quality of their marital relations, facilitating social interaction, reducing problems and crises, improving communication, and avoiding conflicts. According to Villa and Del Prette (2012), Marital Social Skills are essential for the maintenance of marriages, besides influencing the education of their children. Researchers have indicated the use of couple-specific skills to promote relationship enhancement and increase marital satisfaction (Ramos, Barreto, \& Barreto, 2015; Villa \& Del Prette, 2013).

Tissot and Falcke (2017) identified potential sources of stress in the various stages of the family life cycle, which require the couple's involvement in certain tasks which, associated with specific risks, can produce dissatisfaction and even marital separation. Although married individuals reported more feelings of happiness than single, divorced, separated and widowed ones(Soulsby \& Bennett, 2015), in Brazil, the Instituto Brasileiro de Geografia e Estatística (2015) reported an increase of $118.3 \%$ in the number of divorces between 2005-2015.

In the context of romantic relationships, Empathy is described as the ability of individuals to actively understand what their partners feel and to help them anticipate and avoid potential conflicts. The positive association between Empathy and relationship quality has been well established in the literature (Kimmes,

2 Edwards, Wetchler, \& Bercik, 2014; Ulloa, Hammett, Meda, \& Rubalcaba, 2017). 
Love is considered one of the greatest and most intense human feelings. Lee's Theory of Love Styles (Lee, 1988) used the color metaphor as the basis for his love taxonomy proposal. The rainbow has the three primary colors (red, yellow and blue) and from these derive the others. The three primary styles of love are Eros, Storge and Ludus. Eros is the pursuit of a lover with the idealized physical appearance; Storge is a slow process of knowledge, it's about getting used to one's partner, it's companionship; And, Ludus is the game of love. The types of love derived are Mania (Eros + Ludus), characterized by obsession, jealousy and great emotional intensity; Pragma (Ludus + Storge), a type of practical love that considers the demographic and objective characteristics of being loved, and Agape (Eros + Storge) or altruistic love, which is stripped and without expectation of reciprocity (Andrade \& Garcia, 2014).

In Sternberg's Triangular Theory of Love (Sternberg, 2006) there are three basic components: Intimacy, which promotes closeness, bonding, and connection in romantic relationships, and allows for comfort, happiness, and communication to increase; Passion, which leads to romance, physical attraction, sexual intercourse, sexual needs, self-esteem, satisfaction, affiliation, dominance and submission; and Decision/ Commitment, which is characterized by the decision to love and to maintain that love. Commitment is the ability to support and express love, to being faithful, considerate and devoted to the spouse (Anderson, 2016).

According to Rosado and Wagner (2015), in the various stages of family life, couples seek satisfaction and happiness in their relationships. Satisfaction is herein represented by several judgments about the romantic relationship. Marital Satisfaction can be defined as an assessment of the individual resulting from comparing their relationship with models and sociocultural expectations about married life.

The relationship between love and marital satisfaction has been explored in different studies. Passion, Intimacy, and Decision/Commitment were correlated with Marital Satisfaction (Haack \& Falcke, 2014; Hoesni, Kadir, Sulaiman, \& Hafidz, 2016; Kochar \& Sharma, 2015) and Decision/Commitment was the most prominent component (Rizzon, Mosmann, \& Wagner, 2013), while the Eros love style contributed to the Marital Satisfaction of men and women (Ghana, Saada, \& Untas, 2013).

This study aimed to verify the possible predictive relationships between the Social Skills, Marital Social Skills, Empathy, Romantic Love explanatory variables and the Marital Satisfaction criterion variable in men and women in the four stages of the family life cycle determined ad hoc for this investigation.

\section{Method}

\section{Participants}

A total of 446 married heterosexual individuals participated in this study, who were selected by means of a non-probabilistic quota sampling method. Inspired by McGoldrick et al. (2015), the following stages of the family life cycle were defined ad hoc for the recruitment of the current sample: couples without children (G1); couples with children between 0 and 11 years old (G2), couple with adolescent children, from 12 to 17 years old (G3); and couples with children over 18 years old (G4). In G1, 122 (27.2\%); G2, 116 (25.9\%); G3, 102 (23.2\%); and G4, 106 (23.7\%). The participants' ages ranged from 21 to $79(M=43.7, S D=12.25)$ and the duration of relationships from 1 to 55 years $(M=16.3, S D=12.73)$.

\section{Instruments}

A. Del Prette and Del Prette's (2001) Social Skills Inventory (SSI) with 42 items, measured with a five-point Likert scale, which assesses the Coping and Self-Assertion with Risk, Self-Assertion in the Expression 
of Positive Affect, Conversation, and Social Confidence, Self-Exposure to Unknown People or New Situations, and Self-Control of Aggressiveness factors. The Cronbach's alpha coefficients found in the original study were, respectively, 0.96, 0.86, 0.81 and 0.75 (A. Del Prette \& Del Prette, 2001).

Villa and Del Prette's (2012) Marital Social Skills Inventory (MSSI), consisting of 32 items, measured with a five-point Likert scale, addressing social skills in specific marital context situations. The MSSI has five factors: Expressivity/Empathy, Affirmative Self-Assertion, Reactive Self-Control, Proactive Self-Control, and Assertive Conversation. Their internal consistencies (Cronbach's alphas) obtained in the original study were, respectively, 0.68, 0.63, 0.63, 0.60 and 0.53 (Villa \& Del Prette, 2012).

The Empathy Inventory by Falcone et al. (2008) composed of 40 items that measure empathy in life situations through a five-point Likert scale on four factors: Perspective Taking, Interpersonal Flexibility, Altruism, and Affective Sensitivity. Their internal consistency coefficients (Cronbach's alpha) were, respectively, 0.85, $0.78,0.75$ and 0.72 (Falcone et al., 2008).

The Passionate Love Scale (PLS-R) by Hatfield and Sprecher (1986), a one-dimensional reduced version, which measures the intensity of love using 15 items. The items were answered using a 5-point Likert scale: 1 "nothing true" and 5 "totally true". In the current research, the Brazilian adaptation of Hernandez (2015) which presented Cronbach's alpha of 0.91 was used.

The reduced Sternberg Triangular Love Scale (TLS-R) with 15 items, equally divided between the Passion, Intimacy, and Decision / Commitment components. To respond to the TLS-R, subjects used a seven-point Likert scale, where 1 is "nothing true", 4 is "moderately true" and 7 is "totally true". In the adaptation of Hernandez (2016), which is the version used in the present research, the Cronbach's Alphas of the TLS-R ranged from 0.80 to 0.92 .

Andrade and Garcia's Romantic Belief Scale (RBS) (2014), the Brazilian version of the C. Hendrick and Hendrick (1986), Love Styles Scale, with 37 items that evaluate love in six dimensions: Agape, Ludus, Eros, Pragma, Storge and Mania. To assess responding to the RBS items, participants used a five-point Likert scale from 1 (strongly disagree) to 5 (strongly agree). The Cronbach's alpha coefficients obtained were, respectively, $0.84,0.82,0.75,0.69,0.73$ and 0.65 (Andrade \& Garcia, 2014).

Hendrick's (1988) Relationship Assessment Scale (RAS) with seven items that provide a one-dimensional measure of the overall subjective feeling of satisfaction in the romantic relationship. Items are interrogative phrases evaluated using a five-point Likert scale, where 1 is "nothing" and 5 is "totally". In the Brazilian adaptation of the RAS, evidence of factorial validity was revealed and the Cronbach's alpha was 0.87 (Hernandez, 2014).

The project was approved by the Research Ethics Committee of the University to which it is linked by Protocol No. 1567469. All participants were invited to willingly participate in the research, received information about its objectives, read and signed the Informed Consent Form. The instruments were answered individually. Data were collected at the participants' homes and workplaces, and in their educational institutions.

Multiple Linear Regression Analyzes (MLRA) were performed considering as explanatory variables all dimensions that compose the measures of Social Skills (SSI, MSSI), Empathy Inventory, Romantic Love (PLS-R, TLS-R and RBS). and the age of the participants and as a criterion variable the Marital Satisfaction (RAS). An analysis of variance compared the RAS scores between the four stages of the family life cycle.

\section{Results}

The univariate normality test revealed that the distribution of Relationship Assessment Scale (RAS) scores is not normal. However, asymmetry and kurtosis values were -1.029 and 0.115 , respectively, which is 
not an extreme violation of normality (Finney \& DiStefano, 2006). Correlation values between independent variables, regression coefficients and standard errors, respectively, were not high and, therefore, did not suggest the existence of multicollinearity. In addition, the Variance Inflation Factor (VIF) calculation showed no indicator values of multicollinearity, VIF $>5$. In this study, the effect size was represented by the Coefficient of Determination $\left(R^{2}\right)$ and all interpretations of the effect sizes calculated in the MLRA followed the Cohen classification (1988).

For male G1 participants, the MLRA estimated that for each Standard Deviation (SD) of the predictor variable TLS-R Passion, there will be a 0.61 SD variation in the RAS Marital Satisfaction. In this case, the effect size of the explanatory variable on the criterion is strong $\left(R^{2}=0.38\right)$. For female $\mathrm{G} 1$ participants, it was estimated that for each SD of the predictive variables Decision/Commitment of the TLS-R and the RBS Agape, respectively, there will be a variation of 0.62 and 0.38 SD in the Marital Satisfaction of the RAS (Table 1). The effect size of the two explanatory variables on the criterion variable was strong $\left(R^{2}=0.57\right)$. For male $\mathrm{G} 2$ participants, it was estimated that the variation of a SD in the MSSI Proactive Self-Control and SSI Coping and Self-Assertion with Risk variables, respectively, will produce a variation of 0.77 and 0.47 SD in the RAS Marital Satisfaction. The effect size of these predictor variables was strong $\left(R^{2}=0.68\right)$. It was also estimated that the variation of a SD in the El Affective Sensitivity and the SSI Coping and Self-Assertion with Risk explanatory variables, respectively, will produce a variation of 0.58 and 0.32 SDs in the RAS Marital Satisfaction variable for women in the $\mathrm{G} 2$ group (Table 1). This was a strong size effect $\left(R^{2}=0.35\right)$.

In the G3 group, it was estimated that the variation of a SD of the TLS-R Decision/Commitment explanatory variable will have an effect of 0.48 and 0.77 SDs, respectively, for men and women on the Marital Satisfaction criterion variable of the RAS. The sizes of these effects were medium $\left(R^{2}=0.21\right)$ and strong $\left(R^{2}=0.58\right)$, respectively, for men and women (Table 1).

The TLS-R Passion was the most prominent predictive variable for men in the G4 group. The variation of a $S D$ in this variable should produce a variation of $0.88 S D$ in the Marital Satisfaction criterion variable. The effect size of this explanatory variable on the criterion variable was strong $\left(R^{2}=0.76\right)$. For $\mathrm{G} 4$ women, it

Table 1

Multiple Linear Regression Analysis, Stepwise Method, RAS Variable Criterion by Family Life Cycle Group and Sex

\begin{tabular}{|c|c|c|c|c|c|c|c|c|c|}
\hline Group & Sex & Model & Predictor & $R$ & $R_{\text {adjusted }}^{2}$ & Beta $_{\text {standard }}$ & $F$ & $D F$ & VIF \\
\hline \multirow[t]{4}{*}{1} & \multirow[t]{2}{*}{ Male } & 1 & Passion & 0.61 & 0.38 & 0.61 & $35.972^{*}$ & (1.59) & 1.00 \\
\hline & & 1 & Commitment & 0.66 & 0.42 & 0.66 & $45.159^{*}$ & (1.59) & 1.00 \\
\hline & \multirow[t]{2}{*}{ Female } & 2 & Commitment & 0.76 & 0.57 & 0.62 & $39.951^{*}$ & $(2.58)$ & 1.01 \\
\hline & & & Agape & & & 0.38 & & & \\
\hline \multirow[t]{6}{*}{2} & & 1 & Self-proactive & 0.69 & 0.47 & 0.69 & $51.364^{*}$ & $(1.56)$ & 1.00 \\
\hline & \multirow[t]{3}{*}{ Male } & 2 & Self-proactive & 0.83 & 0.68 & 0.77 & $61.931^{*}$ & $(2.55)$ & 1.03 \\
\hline & & & Coping & & & 0.47 & & & \\
\hline & & 1 & Sensitivity & 0.53 & 0.27 & 0.53 & $21.615^{*}$ & $(1.56)$ & 1.00 \\
\hline & \multirow[t]{2}{*}{ Female } & 2 & Sensitivity & 0.61 & 0.35 & 0.58 & $16.640^{*}$ & $(2.55)$ & 1.00 \\
\hline & & & Coping & & & 0.32 & & & \\
\hline \multirow[t]{2}{*}{3} & Male & 1 & Commitment & 0.48 & 0.21 & 0.48 & $14.389^{*}$ & $(1.49)$ & 1.00 \\
\hline & Female & 1 & Commitment & 0.77 & 0.58 & 0.77 & $71.384^{*}$ & $(1.49)$ & 1.00 \\
\hline \multirow[t]{2}{*}{4} & Male & 1 & Passion & 0.88 & 0.76 & 0.88 & $169.422^{*}$ & $(1.51)$ & 1.00 \\
\hline & Female & 1 & Passion & 0.71 & 0.50 & 0.71 & $52.938^{*}$ & $(1.51)$ & 1.00 \\
\hline
\end{tabular}

Note: "Statistical significance level < 0.001. DF: Degrees of Freedom; F: Value an ANOVA Test; R: Coefficient of etermination; VIF: Variance Inflation Factor. 
was estimated that the variation of one SD in the Passion variable of the TLS-R will have a respective effect of $0.71 S D$ on the Marital Satisfaction variable (Table 1). The effect size of this explanatory variable on the criterion variable was strong $\left(R^{2}=0.50\right)$. In addition, the age of the participants had no significant effects identified in the overall Marital Satisfaction, nor in the four stages of the family life cycle, so it was excluded from the MLRA.

A two-way analysis of variance compared the average RAS scores between the family cycle stage variables and the participants' sex. In the results, significant statistical differences for the main effect of the life cycle stage $F(3,440)=6.784, p<0.001$. Tukey's follow-up test identified the differences between $\mathrm{G} 1$ $(M=4.44, S D=0.59)-G 2(M=4.42, S D=0.47)$ and $G 1-G 3(M=4,12, S D=0.62)$, and the effect sizes (ds) were moderate -0.43 and 0.53 , respectively (Cohen, 1988). Mean RAS scores were lower for the $\mathrm{G} 3$ group, of couples with adolescent children, followed by couples with young children. The highest scores were for couples without children and couples with adult children (Table 2). No significant differences were identified in the comparisons between the participants' sexes and also in the interaction of sex with the family life cycle stages.

Table 2

Averages, Standard Deviations, RAS ANOVA by Family Life Cycle Stage and Sex

\begin{tabular}{lccccccccc}
\hline Group & $n$ & $M$ & $S D$ & Sex & $n$ & $M$ & $S D$ & $F(d f)$ & $p$ \\
\hline 1 & 122 & 4.4 & 0.59 & $M$ & 61 & 4.4 & 0.59 & $6.835(3.444)$ & 0.000 \\
& & & & $F$ & 61 & 4.4 & 0.60 & \\
3 & 116 & 4.2 & 0.47 & $M$ & 58 & 4.2 & 0.49 & \\
& 104 & 4.1 & 0.62 & $M$ & 51 & 4.1 & 0.58 & \\
4 & 106 & 4.3 & 0.53 & M & 53 & 4.3 & 0.63 & \\
& & & & $F$ & 53 & 4.3 & 0.42 & \\
\hline
\end{tabular}

Note: $F(d f)$ : Value an ANOVA Test; M: Mean; $n$ : sample size; $p$ : level of significance; SD: Standard Deviation.

\section{Discussion}

It was observed that the predictors of Marital Satisfaction for men and women varied from one stage of the family life cycle to another, which corroborates the idea that each of these moments has its own development, as described by McGoldrick et al. (2015). In the G1 and G2 groups, in which individuals mostly have a shorter marital relationship, the explanatory variables of Marital Satisfaction were different for men and women. On the other hand, the G3 and G4 groups, with longer-term relationships, had the same or similar predictors of Marital Satisfaction for both sexes (Table 1).

In the G1 group, men indicated the TLS-R Passion as the most important factor for Marital Satisfaction. This component of love is generally considered to lead to romance, physical attraction, sexual intercourse (Sternberg, 2006) and therefore plays an important role in the early times of romantic relationships. Few recent studies have reported sexual differences in Passion, with men showing higher levels than women (Ahmetoglu, Swami, \& Chamorro-Premuzic, 2010) and when these differences appear, they are very subtle (Sumter, Valkenburg, \& Peter, 2013).

For women in the G1 group, current data pointed to the TLS-R Decision Commitment and the RBS

6 Agape predictor variables as responsible factors for Marital Satisfaction. The Decision/Commitment variable 
has a short-term dimension, a decision to love each other and a long-term commitment to maintain that love (Sternberg, 2006). These women indicated a tendency to be more satisfied with lovers who are predominantly committed and emotionally involved with the relationship, possibly for the relationship to be safer and more stable.

The relationship based on love, companionship, mutual admiration and individual freedom to build the life trajectory were the elements found in the maintenance of relationships by Borges, Magalhães, and Féres-Carneiro (2014). This style of love is considered as kind, loving and difficult to find, characterized by giving oneself to the partner. In the current data, it is possible to understand women's responses as a search, at the beginning of relationships, for an affectionate, caring partner, for a friend, for commitment and companionship, which are characteristics of the TLS-R Commitment and the RBS Agape constructs. The main explanatory variables for male Marital Satisfaction in the G2 group were Proactive Self-Control and Coping and Self-Assertion with Risk. The Proactive Self-Control factor is characterized by the ability to keep track of emotions as well as reactions. This is essential for the good dialogue between the couple, as well as helping to recognize the emotional state of their spouses, listening to what they have to say, waiting for the right moment to express an opinion, and seeking for an understanding (Villa \& Del Prette, 2012). Different studies have indicated that communication is important in romantic relationships (Lavner, Karney, \& Bradbury, 2016; Schmidt, Luquet, \& Gehlert, 2016). They suggest that when there is dialogue, there is an increase in satisfaction and intimacy. In the contemporary lifestyle, factors such as an excessive involvement with work and a lack of time can make communication and problem solving difficult (Alves-Silva, Scorsolini-Comin, \& Santos, 2016).

For women in the G2 group, Affective Sensitivity appeared as the main predictor variable of Marital Satisfaction. According to Falcone et al. (2008), this factor is characterized by feelings of compassion and interest in the emotional state of the other person and, therefore, a higher score indicates a lot of attention or care towards the other. It should be noted that the G2 group is at the stage of the family cycle characterized by the arrival of children and the change in marital structure. Mothers tend to be more sensitive to hormonal changes, attention, and child-rearing concerns. This is a biological predisposition of women to protect and identify the needs of their babies. This could explain Affective Sensitivity as a predictor of Marital Satisfaction for women in this study.

Coping and Self-Assertion with Risk was the second factor that most affected Male and Female Marital Satisfaction in the G2 group. It portrays interpersonal episodes that lead the individual to react in defense of their own rights, the other people's rights and self-esteem, and may have an undesirable reaction (A. Del Prette \& Del Prette, 2001). In the study by Mosmann and Falcke (2011), couples claimed that the most frequent reason for fights, clashes, stress, conflicts, misunderstanding, and coping between them was raising their children, followed by time spent together, money, household chores, sex and legal issues.

The results of the $\mathrm{G} 2$ group demonstrate that, at this stage of the marital life, the couple may present differences in their perceptions. Husbands have a hard time understanding that they no longer have the exclusive attention from their wives, and women are overloaded with learning how to be both a mother and a wife. Men and women respond differently to changing family dynamics and new responsibilities to their spouse and children. Typically, these differences lead to conflict and dissatisfaction, and even divorce. Bäckström, Kåreholtd, Thorstenssona, Golsäterc, and Mårtensson (2018) pointed the following factors as causes for the higher levels of marital conflict: the fact that women are more vulnerable to depression; women do most household and child care chores; men taking refuge in the workplace. or other activities that make them stay away from home; and a decreased frequency of dialogue and sex.

In the G3 group, men and women indicated the TLS-R Decision/Commitment predictor variable as the main predictor of Marital Satisfaction. Adolescent children demand more companionship and partnership 
in the face of difficulties. Decision/Commitment is linked to support, love and consideration for the spouse (Givertz, Segrin, \& Woszidlo, 2016). This phase, called "companion love" by Hatfield, Pillemer, O'Brien, and Le (2008), involves the decision to keep the relationship above all problems (adolescence), based on the importance of the partner and the romantic relationship, and also for other reasons, such as child rearing, economic dependence, fear of loneliness or lack of strength to start over.

Finally, for men and women in the G4 group, the TLS-R Passion predictor variable contributed the most to explaining Marital Satisfaction. This factor of the Triangular Theory of Love relates to aspects of physical attraction and sexual contact, involving sexual desires, as well as behavioral, affective, and cognitive records of affection by the partner. According to Aboim (2009), contrary to marital dissolutions, the importance attached to both individual and marital well-being and the erotic aspect of Passion is identified as a benefit to marriage. However, Hatfield et al. (2008) reported that Passion, over the years, tends to diminish in the face of other feelings. Older adults reported lower levels of passion than younger adults did, however, this decrease is small (Ahmetoglu et al., 2010). Older women and men still reported moderate to high levels of passionate and erotic love (Grote \& Frieze, 1998).

It was observed that the Passion of the Triangular Theory of Love could be divided into Erotic Passion and Romantic Passion (Gouveia, Carvalho, Santos, \& Almeida, 2013). The Erotic Passion would be the experience of the desires and needs of a physiological nature. This component of love would reach its maximum level within half a year into the relationship. Then it could experience a dramatic decline and, after some stability, a slight decline for around four years. Concomitantly, the Romantic Passion, the idealization of the partner, the intrusive and continuous thoughts, the belief in the omnipotence of love, the desires and needs of love, would tend to grow gradually from the beginning of the relationship. The G4 male and female data from the current study could be reflecting this romantic part of Passion. The couple goes back to living alone when their children leave home to study, travel, live alone and raise their own families. There is a need to return to Passion to maintain a healthy relationship and marital satisfaction.

Jackson, Miller, Oka, and Henry (2014) conducted a meta-analysis of 226 independent samples which make up for over 100,000 participants to test the assumption that women experience less marital satisfaction than men and did not find significant differences between female and male individuals. In the present study, no differences were found between men and women (main effect) and the interaction between the family life cycle variables and sex (interactive effect) on marital satisfaction.

However, differences in levels of marital satisfaction were observed between the stages of the family cycle. The G1 group presented the highest RAS average levels followed by the G4, the G2 and, finally, the G3 group, with the lowest levels (Table 2). For Rios and Gomes (2009), most couples without children reported that this condition provides increased marital and personal satisfaction, given that the time that would be invested in children can be channeled to the dyad and to the individual, which would explain these higher RAS levels.

Lower levels of RAS scores in individuals with children could be explained by the interaction between marital and parental roles. Conjugality and parenting are systems, although distinct ones, which are interconnected. The more spouses feel part of a parental alliance, the greater the proximity and marital satisfaction (Augustin \& Frizzo, 2015). Coparenting demands effective participation, responsibility, and interest in the creation of children. Undoubtedly, there are numerous challenges in the exercise of parenting that can lead to stress, conflict and new adaptations. In the phase of couples with adolescent children, there is a resurgence of difficulties in the exercise of the parental role. Adolescents often put themselves in the position of questioners of family functioning, since they have typical experiences of their age that can generate insecurity, confusion, anguish, ambivalent feelings, and misunderstanding. As a result, effective strategies for 8 dealing with this critical phase are required from parents. According to Augustin and Frizzo (2015), the basic 
components of coparenting are coparental support versus depreciation, the individual agreement on parenting and the division of roles, and managing family interactions. The form of administration of these components will have repercussions on Marital Satisfaction. For Tissot and Falcke (2017), dyadic satisfaction presented the lowest level in individuals with young children and the highest score in individuals with adolescent children.

This study revealed that the TLS-R and the RBS love dimensions had a stronger impact on marital satisfaction in the early and late stages of the family life cycle (G1, G3, and G4). Aspects related to Social Skills had a predominant influence on Marital Satisfaction in the stage of couples with young children (G2), considered the most crucial one of the family life. These data can help couples anticipate crises by pursuing and participating in training programs.

It should be considered that the current results come from a convenience sample and therefore probably do not represent the Brazilian population. On the other hand, it is a sample composed entirely of married individuals, legally or not, and society in general. It is suggested that new investments may use dyadic data to explore possible factors associated with marital satisfaction through samples from different Brazilian regions. All of this, combined with longitudinal designs, would provide more consistent results in examining this variable throughout the family life cycle.

\section{Contributors}

All authors were responsible for the conception, analysis and interpretation of data, review and approval of the final version of the article.

\section{References}

Aboim, S. (2009). Da pluralidade dos afetos: trajetórias e orientações amorosas nas conjugalidades contemporâneas. Revista Brasileira de Ciências Sociais, 24(70), 107-122. http://dx.doi.org/10.1590/50102-69092009000200007

Abreu-Afonso, J., Leal, I., \& Proença, V. (2015). Motivation for conjugality in couples life cycle and its relation to happiness and satisfaction. Psychology, 6, 1394-1412. http://dx.doi.org/10.4236/psych.2015.611136

Ahmetoglu, G., Swami, V., \& Chamorro-Premuzic, T. (2010). The relationship between dimensions of love, personality, and relationship length. Archives of Sex Behavior, 39, 1181-1190. http://dx.doi.org/10.1007/s10508-009-9515-5

Alves-Silva, J. D., Scorsolini-Comin, F., \& Santos, M. A. (2016). Conjugalidade e casamentos de longa duração na literatura científica. Contextos Clínicos, 9(1), 32-50. http://dx.doi.org/10.4013/ctc.2016.91.03

Anderson, J. W. (2016). Sternberg's triangular theory of love. The Wiley Blackwell Encyclopedia of Family Studies (pp.1-3). New York: John Wiley \& Sons Inc. http://dx.doi.org/10.1002/9781119085621.wbefs058

Andrade, A. L., \& Garcia, A. (2014). Escala de crenças sobre amor romântico: indicadores de validade e precisão. Psicologia: Teoria e Pesquisa, 30(1), 63-71. http://dx.doi.org/10.1590/\$0102-37722014000100008

Augustin, D., \& Frizzo, G. B. (2015). A coparentalidade ao longo do desenvolvimento dos filhos: estabilidade e mudança no $1^{\circ}$ e $6^{\circ}$ ano de vida. Interação em Psicologia, 19(1), 13-24. https://doi.org/10.5380/psi.v19i1.29239

Azambuja, J. E. B., \& Jaeger, F. P. (2015). A conjugalidade em casais de meia-idade. Disciplinarum Scientia, 16(1), 123-132. Recuperado em janeiro 20, 2018, de https://www.periodicos.unifra.br/index.php/disciplinarumCH/article/view/18 $44 / 1733$

Bäckström, C., Kåreholtd, I., Thorstenssona, S., Golsäterc, M., \& Mårtensson, L. B. (2018). Quality of couple relationship among first-time mothers and partners, during pregnancy and the first six months of parenthood. Sexual \& Reproductive Healthcare, 17, 56-64. http://dx.doi.org/10.1016/j.srhc.2018.07.001

Barreto, M. J., \& Rabelo, A. A. (2015). A família e o papel desafiador dos pais de adolescentes na contemporaneidade. Pensando Famílias, 19(2), 34-42. Recuperado em janeiro 5, 2018, de http://pepsic.bvsalud.org/pdf/penf/v19n2/ v19n2a04.pdf

Borges, C. C., Magalhães, A. S., \& Féres-Carneiro, T. (2014). Liberdade e desejo de constituir família: percepções de jovens adultos. Arquivos Brasileiros de Psicologia, 66(3), 89-103. Recuperado em janeiro 11, 2018, de http://pepsic. bvsalud.org/pdf/arbp/v66n3/08.pdf 
Cohen, J. (1988). Statistical power analysis for the behavioral sciences. New York: Routledge Academic.

Del Prette, A., \& Del Prette, Z. A. P. (2001). Inventário de Habilidades Sociais (IHS-Del-Prette): manual de aplicação, apuração e interpretação. São Paulo: Casa do Psicólogo.

Doss, B. D., \& Rhoades, G. K. (2017). The transition to parenthood: Impact on couples' romantic relationships. Current Opinion in Psychology, 13, 25-28. http://dx.doi.org 10.1016/j.copsyc.2016.04.003

Dutra-Thomé, L., \& Koller, S. (2014). Emerging adulthood in brazilians of differing socioeconomic status: Transition to adulthood. Paidéia, 24(59), 313-322. http://dx.doi.org/10.1590/1982-43272459201405

Falcone, E. M. O., Ferreira, M. C., Luz, R. C. M., Fernandes, C. S., Faria, C. A., D'Augustin, J. F., ... Pinho, V. D. (2008). Inventário de empatia (I.E.): desenvolvimento e validação de uma medida brasileira. Avaliação Psicológica, 7(3), 321-334. Recuperado em janeiro 7, 2018, de http://pepsic.bvsalud.org/pdf/avp/v7n3/v7n3a06.pdf

Finney, S.J., \& DiStefano, C. (2006). Non-normal and categorical data in structural equation modeling. In G. R. Hancock \& R. O. Mueller (Eds.), Structural equation modeling: A second course (pp.269-314). Greenwich: Information Age Publishing.

Ghana, K., Saada, Y., \& Untas, A. (2013). Effects of love styles on marital satisfaction in heterosexual couples: A dyadic approach. Journal of Marriage \& Family Review, 49(8), 754-772. http://dx.doi.org/10.1080/01494929.2013.834025

Givertz, M., Segrin, C., \& Woszidlo, A. (2016). Direct and indirect effects of commitment on interdependence and satisfaction in married couples. Journal of Family Psychology, 30(2), 214-220. http://dx.doi.org/10.1037/fam0000174

Grote, N. K., \& Frieze, I. H. (1998). 'Remembrance of Things Past': Perceptions of marital love from its beginnings to the present. Journal of Social and Personal Relationships, 15(1), 91-109. http://dx.doi.org/doi 10.1177/0265407598151006

Gouveia, V. V., Carvalho, E. A. B., Santos, F. A., \& Almeida, M. R. (2013). Escala tetrangular do amor: testando sua estrutura e invariância fatorial. Psicologia: Ciência e Profissão, 33(1), 32-45. http://dx.doi.org/10.1590/S1414-9 8932013000100004

Haack, K. R., \& Falcke, D. (2014). Love and marital quality in romantic relationships mediated and non-mediated by internet. Paidéia, 24(57), 105-113. http://doi.org/10.1590/1982-43272457201413

Hatfield, E., \& Sprecher, S. (1986). Measuring passionate love in intimate relationships. Journal of Adolescence, 9, 383-410. http://dx.doi.org/doick5qhn

Hatfield, E., Pillemer, J. T., O'Brien, M. U., \& Le, Y. L. (2008). The endurance of love: Passionate and companionate love in newlywed and long-term marriages. Interpersona, 2, 35-64. http://dx.doi.org/10.5964/ijpr.v2i1.17

Hendrick, C., \& Hendrick, S. (1986). A theory and method of love. Journal of Personality and Social Psychology, 50, 392-402. http://dx.doi.org/10.1037/0022-3514.50.2.392

Hendrick, S. S., (1988). A generic measure of relationship satisfaction. Journal of Marriage and the Family, 50, 93-98. http://dx.doi.org/10.2307/352430

Hernandez, J. A. E. (2014). Evidências de validade da escala de avaliação do relacionamento. Estudos de Psicologia (Campinas), 31, 327-336. http://dx.doi.org/10.1590/0103-166X2014000300001

Hernandez, J. A. E. (2015). Validade de construto da escala de amor apaixonado. Psicologia: Teoria e Prática, 17(3), 133-145. Recuperado em janeiro 18, 2018, de http://editorarevistas.mackenzie.br/index.php/ptp/article/view/7394/5534

Hernandez, J. A. E. (2016). Análise fatorial exploratória e hierárquica da Escala Triangular do Amor. Avaliação Psicológica, 15, 11-20. http://dx.doi.org/10.15689/ap.2016.1501.02

Hoesni, S. M., Kadir, N. A., Sulaiman, W. S. W., \& Hafidz, S. W. M. (2016). Love and marital satisfaction among urban malays: Comparing three groups Length of marriage. Jurnal Psikologi Malaysia, 30(2), 32-41. Retrieved December 13, 2017, from http://spaj.ukm.my/ppppm/jpm/article/viewFile/226/190

Instituto Brasileiro de Geografia e Estatística. (2015). Registro civil 2011: taxa de divórcios cresce 45,6\% em um ano. Recuperado em janeiro 10, 2018, de https://biblioteca.ibge.gov.br/visualizacao/periodicos/135/rc_2015_v42.pdf

Jackson, J. B., Miller, R. B., Oka, M., \& Henry, R. G. (2014). Gender differences in marital satisfaction: A meta-analysis. Journal of Marriage and Family, 76, 105-129. http://dx.doi.org/doi10.1111/jomf.12077

Kimmes, J. G., Edwards, A. B., Wetchler, J. L., \& Bercik, J. (2014). Self and other ratings of dyadic empathy as predictors of relationship satisfaction. The American Journal of Family Therapy, 42(5), 426-437. http://dx.doi.org/10.1080/01 926187.2014 .925374

Kochar, R. K., \& Sharma, D. (2015). Role of love in relationship satisfaction. The International Journal of Indian Psychology, 3(1), 81-107. Retrieved December 13, 2017, from https://www.researchgate.net/publication/318900366_Role_of_ love_in_relationship_satisfaction 
Lavner, J. A., Karney, B. R., \& Bradbury, T. N. (2016). Does couples' communication predict marital satisfaction, or does marital satisfaction predict communication? Journal of Marriage and Family, 78(3), 680-694. http://dx.doi.org/10.1111/ jomf. 12301

Lee, J. A. (1988). Love-styles. In R. J. Sternberg, \& M. Barnes (Eds.), The psychology of love (pp.38-67). New Haven: Yale University Press.

McGoldrick, M., Preto, N. A. G., \& Carter, B. A. (2015). The life cycle in its changing context: individual, family, and social perspectives. In M. McGoldrick, N. G. Preto, \& B. Carter (Eds.), The expanding family life cycle: individual, family and social perspectives (pp.1-44). New York: Pearson Higher.

Mosmann, C., \& Falcke, D. (2011). Conflitos conjugais: motivos e frequência. Revista da SPAGESP, 12(2), 5-16. Recuperado em janeiro 4, 2018, de http://pepsic.bvsalud.org/pdf/rspagesp/v12n2/v12n2a02.pdf

Ponciano, E. L. T. (2015). Autoridade parental em transformação: pais e filhos na adultez emergente. In T. Féres-Carneiro (Org.), Família e casal: parentalidade e filiação em diferentes contextos (pp.57-72). Rio de Janeiro: Perspectiva.

Ponciano, E. L. T., \& Féres-Carneiro, T. (2014). Relação pais-filhos na transição para a vida adulta, autonomia e relativização da hierarquia. Psicologia: Reflexão e Crítica, 27(2), 388-397. http://dx.doi.org/10.1590/1678-7153.201427220

Ramos, K. D., Barreto, D. M., \& Barreto, J. B. M., (2015). As principais habilidades sociais para a satisfação conjugal. Pesquisa em Psicologia, Anais Eletrônicos, 45-53. Recuperado em janeiro 8, 2018, de https://www.google.com/ search?q=As+principais+habilidades+sociais+para+a+satisfa \% C3\%A7\% C3\%A3o+conjugal. +Pesquisa+em+ Psicologia.+Anais+Eletr \% C3\%B4nicos \%2C+4553\&oq=As+principais+habilidades+sociais+para+a+satisfa \% C3\%A7\% C3\%A3o+conjugal.+Pesquisa+em+Psicologia.+Anais+Eletr \% C3\%B4nicos\%2C+4553\&aqs=chrome. 69i57j69i64.485j0j4\&sourceid=chrome\&ie=UTF-8\#

Rios, M. G., \& Gomes, I. C. (2009). Casamento contemporâneo: revisão de literatura acerca da opção por não ter filhos. Estudos de Psicologia, 26(2), 215-225. Recuperado em dezembro 20, 2018, de http://www.scielo.br/pdf/estpsi/ v26n2/09.pdf

Rizzon, A. L. C., Mosmann, C. P., \& Wagner, A. (2013). A qualidade conjugal e os elementos do amor: um estudo correlacional. Contextos Clínicos, 6(1), 41-49. http://dx.doi.org/doi 10.4013/ctc.2013.61.05

Rosado, J. S., \& Wagner, A. (2015). Qualidade, ajustamento e satisfação conjugal: revisão sistemática da literatura. Pensando Famílias, 19(2), 21-33. Recuperado em janeiro 11, 2018, de http://pepsic.bvsalud.org/pdf/penf/v19n2/v19n2a03.pdf

Schmidt, C., Luquet, W., \& Gehlert, N. C. (2016). Evaluating the impact of the "getting the love you want" couples workshop on relational satisfaction and communication patterns. Journal of Couple \& Relationship Therapy, 15(1), 1-18. http://dx.doi.org/10.1080/15332691.2014.978061

Soulsby, L. K., \& Bennett, K. M. (2015). Marriage and psychological wellbeing: The role of social support. Psychology, 6, 1349-1359. http://dx.doi.org/10.4236/psych.2015.611132

Sternberg, R. J. (2006). A duplex theory of love. In R. J. Sternberg \& K. Weis (Eds.), The new psychology of love (pp.184-199). New Haven: Yale University Press.

Sumter, S. R., Valkenburg, P. M., \& Peter, J. (2013). Perceptions of love across the lifespan: Differences in passion, intimacy, and commitment. International Journal of Behavioral Development, 37(5), 417-427. http://dx.doi. org/10.1177/0165025413492486

Tissot, W., \& Falcke, D. (2017). A conjugalidade nas diferentes etapas do ciclo vital familiar. Quaderns de Psicologia, 19(3), 265-276. http://dx.doi.org/10.5565/rev/qpsicologia.1399

Ulloa, E. C., Hammett, J. F., Meda, N. A., \& Rubalcaba, S. J. (2017). Empathy and romantic relationship quality among cohabitating couples: An actor-partner interdependence model. The Family Journal: Counseling and Therapy for Couples and Families, 25(3), 208-214. http://dx.doi.org/10.1177/1066480717710644

Villa, M. B., \& Del Prette, Z. A. P. (2012). Inventário de habilidades sociais conjugais (IHSC-Villa \& Del-Prette): manual de aplicação, apuração e interpretação. São Paulo: Casa do Psicólogo.

Villa, M. B., \& Del Prette, Z. A. P. (2013). Marital satisfaction: The role of social skills of husbands and wives. Paidéia, 23(56), 379-387. http://dx.doi.org/10.1590/1982-43272356201312

Received: September 18, 2018

Final version: June 24, 2019

Approved: September 5, 2019 